\title{
Internal Thoracic Artery Patency Before and After Insertion of Specially Designed Pectus Bar
}

\author{
Nezih Onur Ermerak, ${ }^{1}$ Pınar Kuru Bektaşoğlu, ${ }^{2,3}$ Canan Çimşit, ${ }^{4}$ \\ Nuri Çağatay Çimşit,, ${ }^{4}$ ural Bekiroğlu, ${ }^{5}$ Mustafa Yüksel ${ }^{1}$
}

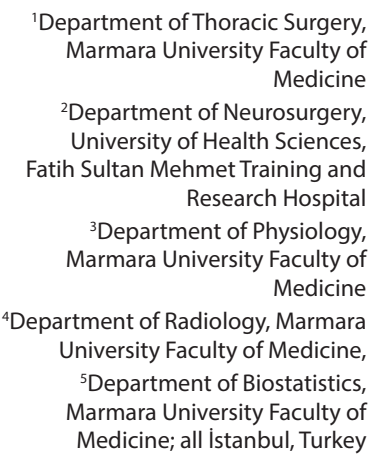

'Department of Thoracic Surgery, Marmara University Faculty of Medicine

2Department of Neurosurgery, University of Health Sciences, Fatih Sultan Mehmet Training and Research Hospital ${ }^{3}$ Department of Physiology, Marmara University Faculty of Medicine

${ }^{4}$ Department of Radiology, Marmara University Faculty of Medicine ${ }^{5}$ Department of Biostatistics, Marmara University Faculty of Medicine; all İstanbul, Turkey

Submitted: 06.10.2016 Accepted: 12.10.2016

Correspondence: Mustafa Yüksel Marmara Üniversitesi Tıp Fakültesi, Göğüs Cerrahisi Anabilim Dalı, İstanbul, Turkey

E-mail:drmustafayuksel@gmail.com

\section{(a)

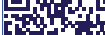 $17+$

Keywords: Chest wall deformity; computed tomography-angiography; funnel chest; minimally invasive; pectus excavatum.

\begin{abstract}
Objective: Blood flow in internal thoracic arteries (ITAs) may become blocked in patients who have had minimally invasive repair of pectus excavatum (MIRPEx). Aim of this study was to investigate patency of ITAs in patients who underwent MIRPEx with pectus bars that were specially designed to protect ITAs.
\end{abstract}

Methods: Total of 22 patients over the age of 16 years who were to undergo correction of pectus excavatum (PEx) were included in this study. Patients with previous surgical intervention for PEx were excluded. Computed tomography-angiography (CTA) of the thorax was performed preoperatively on all patients to evaluate ITA blood flow. MIRPEx procedure included use of specially designed bars in all cases. On postoperative $10^{\text {th }}$ day, follow-up CTA of the thorax was performed. Pre- and postoperative CTAs were compared to determine any effect of bars on ITAs.

Results: Study group comprised 19 male patients and 3 female patients; mean age was $18.8 I \pm 2.48$ years (range: $16-23$ years). Blood flow was not affected in 18 patients $(88.8 \%)$ and was unilaterally blocked in 4 patients (18.2\%) after the operation.

Conclusion: Results demonstrate that only I in 5 patients had unilateral ITA occlusion following MIRPEx with uniquely designed bar.

\section{INTRODUCTION}

Pectus excavatum (PEx) is the most common anterior chest wall deformity. ${ }^{[1,2]}$ It is characterized by posterior depression of sternum and costal cartilages. ${ }^{[3]}$ Manubrium and first 2 cartilages are usually in normal position. ${ }^{[4]}$ Typical presentation of PEx is narrow chest, dorsal lordosis, "hook shoulder" deformity, protruding costal cartilages, and poor posture. ${ }^{[5]}$ PEx is well tolerated in infancy and early childhood, and is usually asymptomatic. In older patients, shortness of breath and palpitations may be seen. ${ }^{[6]}$ When symptomatic cases are investigated for respiratory or cardiac signs, often no obvious pathology can be detected. PEx may be accepted as body dysmorphism with psychosocial consequences. Decreased quality of life is prominent finding in clinical setting. ${ }^{[7]}$ Surgical correction of PEx improves quality of life by addressing physiological and cosmetic problems, which may help to alleviate psychological symptoms.

Ravitch sternoplasty is classic operative technique defined in 1949 and subsequently modified. ${ }^{[8]}$ Due to obvious surgical scar on the chest after Ravitch procedure, minimally invasive repair of PEx (MIRPEx) gained popularity for correction of PEx. This method first described by Dr. Nuss in 
1987 and published in 1998 is also called Nuss procedure. [9] Curved nickel and stainless steel bar is placed under the sternum with thoracoscope. Pressure exerted by bar aids in repositioning skeletal structure. Bar is later removed in second operation. Blood flow of internal thoracic arteries (ITAs) may be compromised by pectus bar; diminished or obstructed flow has been reported in several studies. ${ }^{[10,11]}$ The present study sought to evaluate effect of bars specially designed bars to preserve ITA patency.

\section{PATIENTS AND METHODS}

This prospective study was conducted between April 2014 and December 2014 with approval of the Yeditepe University Faculty of Medicine ethics committee (date: March II, 2014; number: 402) and with written, informed consent of all study patients. Total of 22 patients between 16 and 23 years of age ( 19 male and 3 female patients with mean age of $18.81 \pm 2.48$ years) with PEx deformity who were to undergo Nuss procedure were enrolled in the study. Preoperative thorax computed tomography angiography (CTA) was performed and ITA blood flow was evaluated by 2 experienced radiologists (Figure I). Patients under 16 years of age, with history of thoracic surgery, whose prominent costochondral deformity cannot be corrected with this procedure, and patients with abnormal ITA blood flow were not included in the study. Preoperative evaluation consisted of respiratory function tests, electrocardiography, posteroanterior and lateral chest X-rays, and complete blood count. Detailed explanation of surgical technique has been provided elsewhere. ${ }^{[12,13]}$ In the operation, specially designed pectus bars shaped to provide a channel that protects ITAs and prevents bar-induced pressure (Tasarimmed Tibbi Mamüller San. ve Tic. Ltd. Şti., Figure 2) were inserted. On postoperative 10th day, second thorax CTA was performed to evaluate blood flow in ITAs. According to blood flow characteristics, patients were divided into 2 groups: Patients with normal blood flow and no change in patency formed the unaffected group (Group I), and patients with diminished blood flow (monophasic low flow rate) or obstruction (no flow), bilaterally or unilaterally, made up the affected group (Group 2). Patient data were analyzed according to gender, age, symmetry of deformity, Haller index value, and number of pectus bars inserted.

\section{Statistical analysis}

All analyses were performed using SPSS for Windows, version 17.0 (IBM Corp., Armonk, NY, USA). Patient characteristics were evaluated using descriptive statistics. Categorical data comparisons were performed using Fisher's exact test. For continuous data comparisons of the 2 groups, Student's t-test was performed. $P$ value $<0.05$ was accepted as statistically significant. In presentation of descriptive
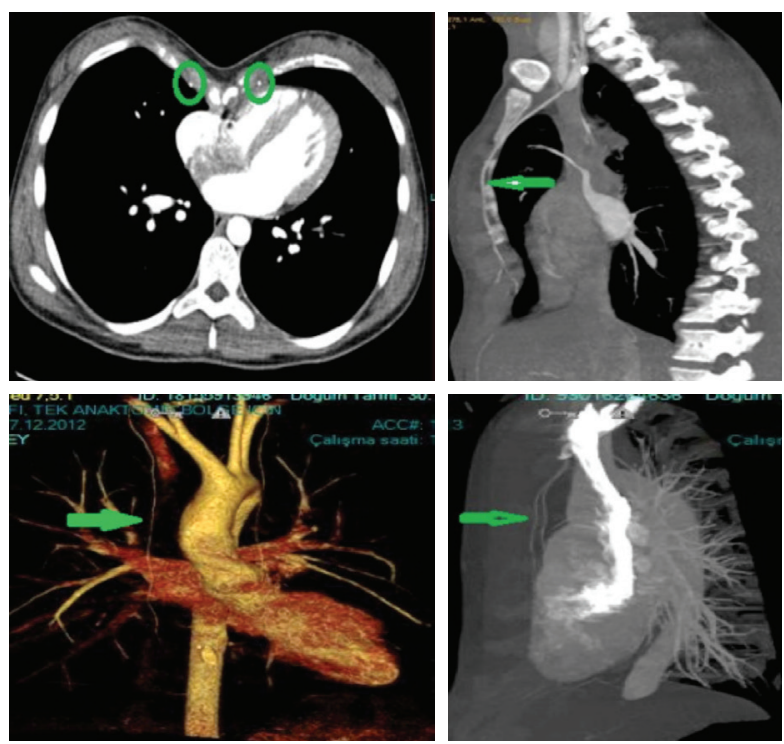

Figure 1. Preoperative thorax computed tomography angiography illustrating patent internal thoracic arteries with normal blood flow (green circles and arrows).

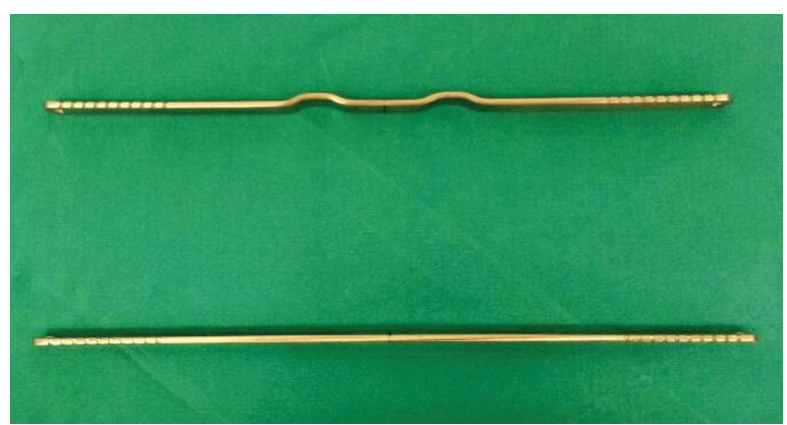

Figure 2. The specially designed pectus bar (above) used in this study with visible arches, and standard pectus bar (below).

statistics, continuous data were presented as mean $\pm S D$, and categorical data as frequencies and percentages.

\section{RESULTS}

Total of 19 male and 3 female patients with age range of between 16 and 23 years (Median age: 18 years; mean age: $18.81 \pm 2.48$ years) were included in the study. Patient age, gender, deformity type, Haller index value, number of bars inserted, and bar length data are provided in Table I. On postoperative 10th day, thorax CTA was performed to reevaluate blood flow in ITAs. Table 2 illustrates comparison of affected and unaffected groups by age, gender, deformity type, Haller index, and number of bars used. Blood flow was not affected in 18 patients (Figure 3). Only 4 patients exhibited unilateral blood flow obstruction (Figure 4). Detail of type of unilateral involvement is presented in Table 3. There were no statistically significant differences found between groups in terms of age, gender, deformity type, Haller index value, or number of bars used (Table 
Table 1. Age, gender, deformity type, Haller index value, number and length of bars used for all patients

\begin{tabular}{lcccccc}
\hline Patient & Gender & $\begin{array}{c}\text { Age (Years) } \\
(18.81 \pm 2.48)\end{array}$ & $\begin{array}{c}\text { Deformity } \\
(\mathrm{A} / \mathrm{S})^{\#}\end{array}$ & $\begin{array}{c}\text { Haller index } \\
(3.35 \pm 0.95)\end{array}$ & $\begin{array}{c}\text { Number of bar } \\
\text { inserted }\end{array}$ & $\begin{array}{c}\text { Bar lenghth } \\
(\mathrm{mm})\end{array}$ \\
\hline 1 & Male & 18 & Symmetric & 5.00 & 2 & $208+305$ \\
$\mathbf{2}$ & Male & $\mathbf{1 7}$ & Symmetric & $\mathbf{3 . 8 6}$ & $\mathbf{1}$ & $\mathbf{3 1 0}$ \\
$\mathbf{3}$ & Male & $\mathbf{2 0}$ & Asymmetric & $\mathbf{2 . 8 6}$ & $\mathbf{2}$ & $\mathbf{3 5 0 + 3 2 0}$ \\
4 & Male & 22 & Symmetric & 3.00 & 2 & $330+310$ \\
5 & Male & 21 & Symmetric & 2.63 & 1 & 305 \\
6 & Male & 16 & Symmetric & 6.67 & 1 & 280 \\
7 & Female & 19 & Symmetric & 3.17 & 1 & 280 \\
8 & Male & 16 & Symmetric & 3.00 & 1 & 305 \\
9 & Male & 20 & Symmetric & 3.00 & 2 & $330+330$ \\
10 & Male & 17 & Symmetric & 3.14 & 1 & 305 \\
11 & Male & 18 & Symmetric & 2.25 & 1 & 330 \\
12 & Male & 21 & Symmetric & 3.33 & 1 & 330 \\
13 & Female & 16 & Symmetric & 2.83 & 1 & 260 \\
14 & Male & 18 & Symmetric & 3.61 & 1 & 280 \\
15 & Male & 18 & Symmetric & 3.60 & 1 & 330 \\
16 & Male & 16 & Symmetric & 2.82 & 1 & 288 \\
$\mathbf{1 7}$ & Male & $\mathbf{1 6}$ & Symmetric & $\mathbf{2 . 5 0}$ & $\mathbf{1}$ & $\mathbf{2 8 0}$ \\
18 & Male & 23 & Asymmetric & 3.80 & 1 & 330 \\
19 & Male & 22 & Symmetric & 2.53 & 2 & $355+355$ \\
$\mathbf{2 0}$ & Male & $\mathbf{1 6}$ & Symmetric & $\mathbf{3 . 0 0}$ & $\mathbf{1}$ & $\mathbf{3 0 5}$ \\
21 & Male & 23 & Symmetric & 3.89 & 2 & $280+320$ \\
22 & Male & 21 & Symmetric & 3.42 & 1 & 330 \\
\hline
\end{tabular}

Data for patients with obstructed internal thoracic arteries are presented in bold and italic type.

Table 2. Comparison of affected and unaffected groups based on age, gender, deformity type, Haller index value, and number of bars inserted

\begin{tabular}{lcccccccc}
\hline Group & $\begin{array}{c}\text { No. of } \\
\text { patient }\end{array}$ & $\begin{array}{c}\text { Gender } \\
(\mathrm{M} / \mathrm{F})^{*}\end{array}$ & $\begin{array}{c}\text { Age } \\
\text { (years) }\end{array}$ & $\begin{array}{c}\text { Deformity } \\
(\mathrm{S})^{*}\end{array}$ & $\begin{array}{c}\text { Deformity } \\
(\mathrm{A})^{*}\end{array}$ & Haller index & $\begin{array}{c}\text { Bar } \\
(\mathrm{n}=1)\end{array}$ & $\begin{array}{c}\text { Bar } \\
(\mathrm{n}=2)\end{array}$ \\
\hline I & 18 & $15 / 3$ & $19.11 \pm 2.54$ & 17 & 3 & $3.36 \pm 0.94$ & 14 & 4 \\
II & 4 & $4 / 0$ & $17.5 \pm 1.91$ & 1 & 1 & $3.34 \pm 1.12$ & 2 & 2 \\
$p$ value & & $1.00 / 1.00$ & $0.683^{* *}$ & $0.338^{*}$ & $0.338^{*}$ & $0.953^{* *}$ & $0.292^{*}$ & $0.292^{*}$ \\
\hline
\end{tabular}

Group 1: unaffected patients, Group 2: affected patients; M: Male; F: Female; S: Symmetric, A: Asymmetric; ${ }^{*}$ Chi-square test; ${ }^{* * T-\text { test. }}$

2; $p>0.05)$. There were no female patients in group with compromised blood flow (Table 2; $p=1.00$ ). Mean age of patients in unaffected group was $19.11 \pm 2.54$ years, and $17.5 \pm 1.91 \quad(p=0.683)$ years in affected group. Asymmetric deformity was observed in only I patient in each group $(p=0.338)$. Mean Haller index value of affected group was $3.34 \pm 1.12$, and $3.36 \pm 0.94$ in unaffected group $(p=0.953)$. There were only 2 patients in each group who required use of 2 bars $(p=0.292)$.

\section{DISCUSSION}

MIRPEx procedure became popular in the beginning of 2 Ist century, and is preferred by many clinics around the world. Low rates of morbidity and mortality, as well as satisfactory cosmetic results make this technique preferable to earlier options. However, in some case series, high complication rates of $15 \%$ to $63 \%$ have been reported, most often pneumothorax or need for bar 

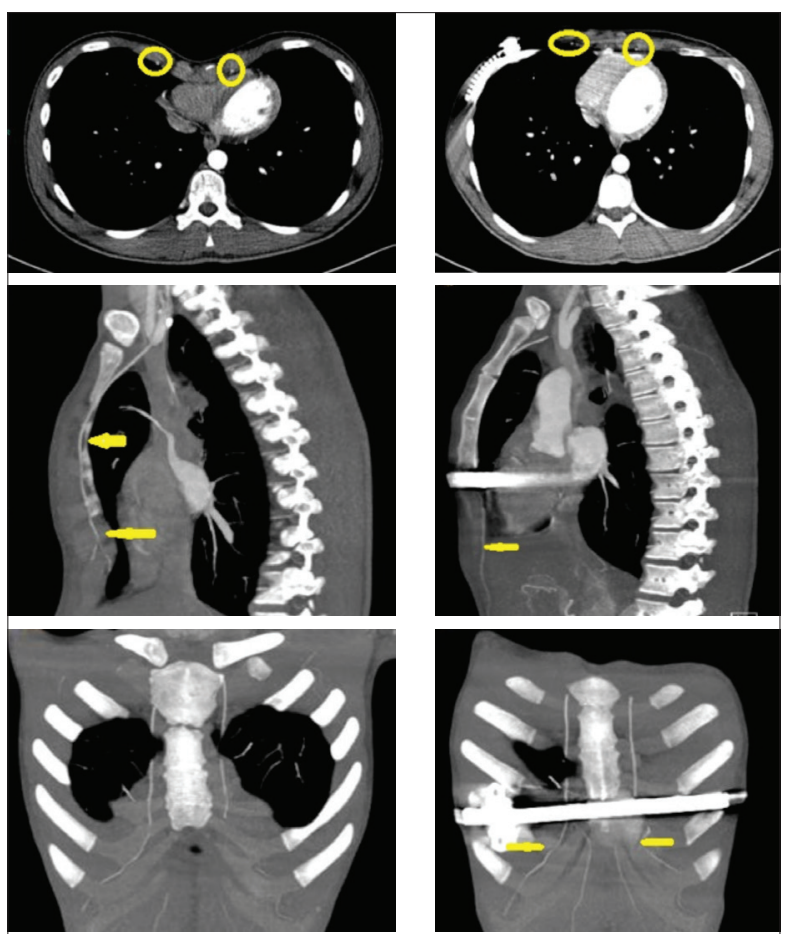

Preoperative

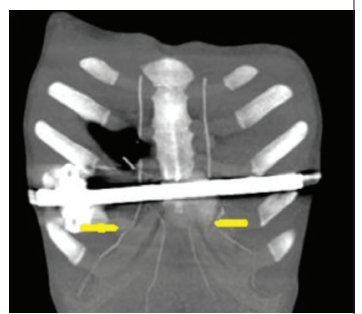

Postoperative

Figure 3. Unaffected internal thoracic arteries in postoperative period (yellow arrows).
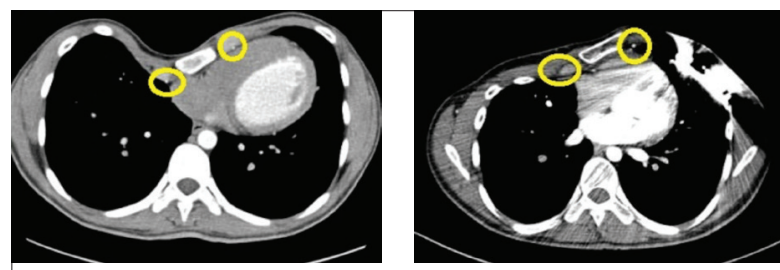

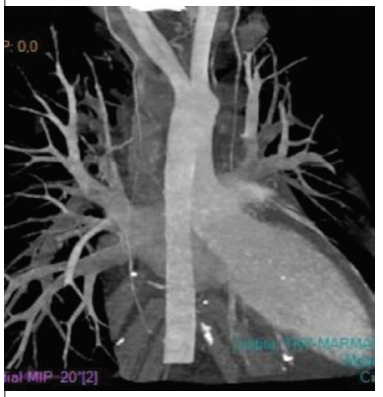

Preoperative

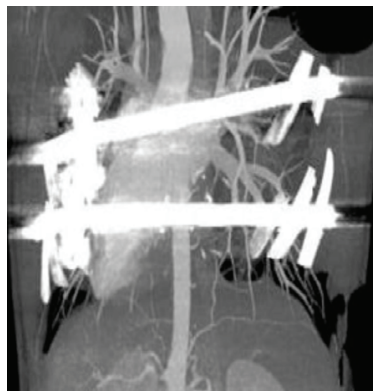

Postoperative
Figure 4. Unilaterally obstructed postoperative internal thoracic arteries (yellow circles).

replacement. ${ }^{[14-18]}$ Incision site seroma, pleural effusion, pericarditis, pericardial effusion, hemothorax, atelectasis, sternal fracture, diaphragm hernia, and bleeding have also been reported..$^{[15,19-23]}$ In I review of 19 reports, no mortality was observed and morbidity was reported as $15.4 \%{ }^{[24]}$ Occasional case reports have been published about death after Nuss procedure due to right atrial and ventricular laceration, or cardiac tamponade. ${ }^{[25-27]}$ Recent
Table 3. Details of occlusion and type of involvement

\begin{tabular}{|c|c|c|}
\hline \multirow[t]{2}{*}{$\begin{array}{l}\text { Patient } \\
(\mathrm{n}=4)\end{array}$} & \multicolumn{2}{|c|}{$\begin{array}{l}\text { Postoperative blood flow of } \\
\text { internal thoracic artery }\end{array}$} \\
\hline & Left & Right \\
\hline 1 & Non-effected & $\begin{array}{l}\text { Occluded after } \\
\text { lower bar }\end{array}$ \\
\hline 3 & $\begin{array}{l}\text { Occluded after } \\
\text { upper bar }\end{array}$ & Non-effected \\
\hline 17 & Non-effected & Occluded \\
\hline 20 & Occluded & Non-effected \\
\hline
\end{tabular}

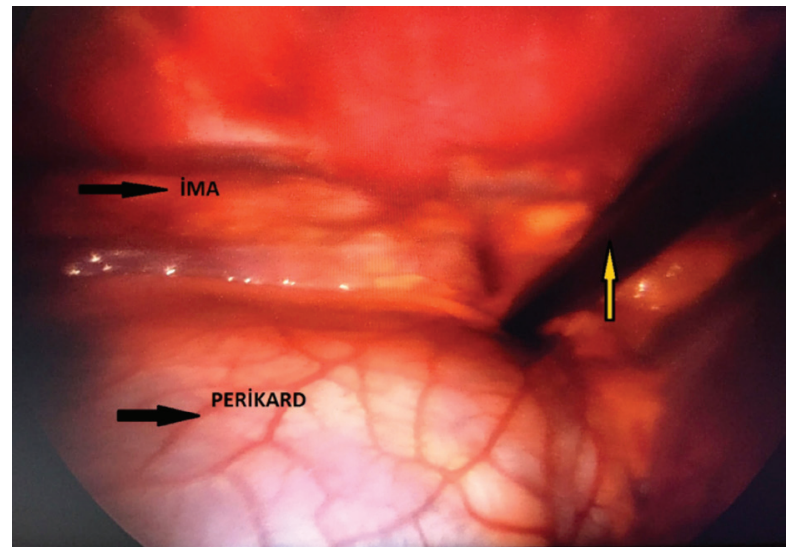

Figure 5. Pectus bar superimposed over internal thoracic artery seen with thoracoscope (yellow arrow).

advances in surgical techniques may help prevent complications and lead to fewer events occurring in peri- and postoperative period of Nuss procedure.

ITAs are located at posterior side of the sternum and pectus bar is superimposed over them. Some studies have addressed ITA blood flow occlusion after Nuss procedure. Yuksel and colleagues reported $44.1 \%$ of patients who underwent Nuss procedure with classic, straight bar had affected ITA blood flow. ${ }^{[10]}$ Pressure exerted by pectus bar could also be observed with thoroscopy (Figure 5). In the present study, we aimed to preserve ITA blood flow via specially designed pectus bars bent to arch over ITAs. Blood flow before and after the operation was examined using thorax CTA. Thorax CTA findings obtained before the procedure were also used to design the personalized pectus bars. Hypothesis was that individually designed bars would not create pressure on ITAs and obstruct ITA blood flow. There was no ITA occlusion in $81.8 \%$ of the patients $(n=18)$ in this study; only $18.2 \%$ of the patients $(n=4)$ had unilateral occlusion (right ITA in 2 patients and left ITA in 2 patients) after the Nuss procedure. There was no statistically significant difference 
between groups according to age, gender, deformity type (symmetric/asymmetric), Haller index value, or number of bars used. When compared with previous report of $44.1 \%$ of patients with compromised ITAs when classic bar was used, current study result was occlusion in only $18.2 \%$ of patients. ${ }^{[10]}$

Some complications were experienced. Pneumothorax occurred in 3 patients. Needle aspiration was required in I case; the other 2 patients had spontaneous recovery. In I patient, scar tissue inflammation developed and was revised surgically. In 2 patients there was chronic drainage of pus. One case resolved after lower bar was removed. The other case resolved with cortisone treatment. In I patient there was hyperpigmentation at site of bar insertion. In I patient, ITA aneurysm occurred due to trauma exerted by bar during insertion and turning process. In another patient, we had to remove the bar before end of treatment period due to pain complaint. After these 2 cases, study was terminated with total of 22 patients.

To conclude, in the present study, specially designed pectus bars were used in MIRPEx procedure to decrease pressure on ITAs. Only I in 5 patients subsequently experienced unilateral ITA occlusion. In future, it may be possible to avoid pectus bar-induced ITA occlusion. However, at present it is still unclear why some patients still manifested ITA occlusion. ITA evaluation before and after bar removal surgery could provide valuable information to determine if occlusion is reversible or irreversible.

Conflict of interest

None declared.

\section{REFERENCES}

1. Brochhausen C, Turial S, Müller FK, Schmitt VH, Coerdt W, Wihlm JM, et al. Pectus excavatum: history, hypotheses and treatment options. Interact Cardiovasc Thorac Surg 2012;14:801-6.

2. Kuru P, Cakiroglu A, Er A, Ozbakir H, Cinel AE, Cangut B, et al. Pectus Excavatum and Pectus Carinatum: Associated Conditions, Family History, and Postoperative Patient Satisfaction. Korean J Thorac Cardiovasc Surg 2016;49:29-34.

3. Schamberger RC. Chest wall deformities. In: Shields TW, Locicero III J, Reed CE, Feins RH, editors. General thoracic surgery. 7th ed. Philadelphia: Lippincott Williams \& Wilkins; 2009. p. 599.

4. Huddleton CB. Chest wall deformities. In: Patterson GA, Cooper JD, Deslauriers J, Lerut AEMR, Luketich JD, Rice TW, editors. Pearson's Thoracic\&Esophageal Surgery. 3rd ed. Philedelphia: Churchill Livingstone Elsevier; 2008. p. 1236.

5. Shields T, Locicero J III, Reed C, Feins RH. General thoracic surgery. 7th edition. Philadelphia: Lippincott Williams and Wilkins; 2009.

6. Kuru P, Dudakli A, Mursaloglu H, Arikan H, Oktay A, Yuksel M. How pulmonary function changes after pectus excavatum correction surgery. Asian Cardiovasc Thorac Ann 2015;23:945-9.

7. Kuru P, Bostanci K, Ermerak NO, Bahadir AT, Afacan C, Yuksel M. Quality of life improves after minimally invasive repair of pectus excavatum. Asian Cardiovasc Thorac Ann 2015;23:302-7.
8. Ravitch MM. The operative treatment of pectus excavatum. Ann Surg 1949;129:249.

9. Nuss D, Kelly RE Jr, Croitoru DP, Katz ME. A 10-year review of a minimally invasive technique for the correction of pectus excavatum. J Pediatr Surg 1998;33:545-52.

10. Yüksel M, Özalper MH, Bostanci K, Ermerak NO, Cimşit Ç, Tasali $\mathrm{N}$, et al. Do Nuss bars compromise the blood flow of the internal mammary arteries? Interact Cardiovasc Thorac Surg 2013;17:5715.

11. Külcü K, Elenbaas TW, Nguyen DT, Verhees RP, Mihl C, Verberkmoes NY, et al. Patency of the internal mammary arteries after removal of the Nuss bar: an initial report. Interact Cardiovasc Thorac Surg 2014;19:6-9.

12. Umuroglu T, Bostanc1 K, Thomas DT, Yuksel M, Gogus FY. Perioperative anesthetic and surgical complications of the Nuss procedure. J Cardiothorac Vasc Anesth 2013;27:436-40.

13. Yüksel M, Bostanci K, Evman S. Minimally invasive repair after inefficient open surgery for pectus excavatum. Eur J Cardiothorac Surg 2011;40:625-9.

14. Kelly RE Jr, Mellins RB, Shamberger RC, Mitchell KK, Lawson ML, Oldham KT, et al. Multicenter study of pectus excavatum, final report: complications, static/exercise pulmonary function, and anatomic outcomes. J Am Coll Surg 2013;217:1080-9.

15. Park HJ, Lee SY, Lee CS. Complications associated with the Nuss procedure: analysis of risk factors and suggested measures for prevention of complications. J Pediatr Surg 2004;39:391-5.

16. Hebra A, Swoveland B, Egbert M, Tagge EP, Georgeson K, Othersen $\mathrm{HB} \mathrm{Jr}$, et al. Outcome analysis of minimally invasive repair of pectus excavatum: review of 251 cases. J Pediatr Surg 2000;35:2528.

17. Pilegaard HK, Licht PB. Early results following the Nuss operation for pectus excavatum-a single-institution experience of 383 patients. Interact Cardiovasc Thorac Surg 2008;7:54-7.

18. Kabbaj R, Burnier M, Kohler R, Loucheur N, Dubois R, Jouve JL. Minimally invasive repair of pectus excavatum using the Nuss technique in children and adolescents: indications, outcomes, and limitations. Orthop Traumatol Surg Res 2014;100:625-30.

19. Castellani C, Schalamon J, Saxena AK, Höellwarth ME. Early complications of the Nuss procedure for pectus excavatum: a prospective study. Pediatr Surg Int 2008;24:659-66.

20. Leonhardt J, Kubler JF, Feiter J. Complications of the minimally invasive repair of pectus excavatum. J Pediatr Surg 2005;40:7-9.

21. Moss RL, Albanese CT, Reynolds M. Major complications after minimally invasive repair of pectus excavatum: case reports. J Pediatr Surg 2001;36:155-8.

22. Marusch F, Gastinger I. Life-threatening complication of the Nuss-procedure for funnel chest. A case report. Zentralbl Chir 2003;128:981-4.

23. Nuss D, Croitoru DP, Kelly RE Jr, Goretsky MJ, Nuss KJ, Gustin TS. Review and discussion of the complications of minimally invasive pectus excavatum repair. Eur J Pediatr Surg 2002;12:230-4.

24. Protopapas AD, Athanasiou T. Peri-operative data on the Nuss procedure in children with pectus excavatum: independent survey of the first 20 years' data. J Cardiothorac Surg 2008;3:40.

25. Schaarschmidt K, Lempe M, Schlesinger F, Jaeschke U, Park W, Polleichtner S. Lessons learned from lethal cardiac injury by nuss repair of pectus excavatum in a 16-year-old. Ann Thorac Surg 2013;95:1793-5.

26. Yang MH, Cheng YL, Tsai CS, Li CY. Delayed cardiac tamponade after the Nuss procedure for pectus excavatum: a case report and 
simple management. Heart Surg Forum 2008;11:129-31.

27. Hoel TN, Rein KA, Svennevig JL. A life-threatening complica- tion of the Nuss procedure for pectus excavatum. Ann Thorac Surg $2006 ; 81: 370-2$.

\section{Özel Tasarlanmış Pektus Barı Yerleşimi Öncesi ve Sonrasında İnternal Torasik Arter Akımının Değerlendirilmesi}

Amaç: Kunduracı göğsü (pektus ekskavatum-PE) minimal invaziv yöntemle onarılmış (MIRPEx) hastalarda internal torasik arterler (iTA'lar) içinden geçen kan akımı bloke olabilir. Bu çalışmanın amacı ITA'ları koruma amacıyla özellikle tasarlanmış pektus barları kullanılarak MIRPEx olmuş hastalarda ITA'ların patensini araştırmaktı.

Gereç ve Yöntem: Bu çalışmaya, PE düzeltmesi yapılacak olan 16 yaş üstü 22 hasta dahil edildi. Daha önceden PE nedeniyle ameliyat edilen hastalar çalışmaya alınmadı. Bilgisayarlı tomografi-anjiyografi (BTA) tüm hastalara ITA akımını değerlendirmek için ameliyat öncesi yapıldı. Tüm hastalar özel tasarım pektus barı ile ameliyat edildi. Ameliyat sonrası 10. günde toraksın kontrol BTA'sı çekildi. Ameliyat öncesi ve sonrası BTA'lar ITA akımını değerlendirmek amacıyla karşılaştırıldı.

Bulgular: Çalışma grubunda 19 erkek 3 kadın hastanın yaş ortalamaları I8.8I \pm 2.48 (dağılım, I6-23 yıl) idi. On sekiz hastada kan akımı etkilenmemişti (\%88.8) ve sadece dört hastada tek taraflı iTA tıkanması mevcuttu.

Sonuç: Sonuçlar, benzersiz bir şekilde tasarlanmış barla MIRPEx sonrasında, 5 hastanın sadece I'inde tek taraflı ITA tıkanması olduğunu gösterdi.

Anahtar Sözcükler: Göğüs duvarı deformitesi; bilgisayarlı tomografi- anjiyografi; kunduracı göğsü; minimal invaziv; pektus ekskavatum. 